\title{
INDOLEACETIC ACID PRODUCTION AND PLANT GROWTH PROMOTING POTENTIAL OF BACTERIAL ENDOPHYTES ISOLATED FROM RICE (ORYZA SATIVA L.) SEEDS
}

\author{
Raheem Shahzad, ${ }^{1}$ Muhammad Waqas, ${ }^{1,2}$ Abdul Latif Khan, ${ }^{3}$ \\ Khadija Al-Hosni, ${ }^{1,3}$ Sang-Mo Kang, ${ }^{1}$ Chang-Woo SeO ${ }^{1}$ and In-Jung LeE ${ }^{1,4 *}$ \\ ${ }^{1}$ School of Applied Biosciences, Kyungpook National University, Daegu 41566, Republic of Korea \\ ${ }^{2}$ Department of Agriculture Extension, Buher 19290, Khyber Pakhtunkhwa, Pakistan \\ ${ }^{3}$ UoN Chair of Oman's Medicinal Plants \& Marine Natural Products, University of Nizwa, \\ Nizwa 616, Oman \\ ${ }^{4}$ Research Institute for Dok-do and Ulleung-do Island, Kyungpook National University, \\ Daegu 41566, Republic of Korea
}

(Received: June 15, 2016; accepted: February 7, 2017)

\begin{abstract}
Bacterial endophytes from the phyllosphere and rhizosphere have been used to produce bioactive metabolites and to promote plant growth. However, little is known about the endophytes residing in seeds. This study aimed to isolate and identify seed-borne bacterial endophytes from rice and elucidate their potential for phytohormone production and growth enhancement. The isolated endophytes included Micrococcus yunnanensis RWL-2, Micrococcus luteus RWL-3, Enterobacter soli RWL-4, Leclercia adecarboxylata RWL-5, Pantoea dispersa RWL-6, and Staphylococcus epidermidis RWL-7, which were identified using $16 \mathrm{~S}$ rRNA sequencing and phylogenetic analysis. These strains were analyzed for indoleacetic acid (IAA) production by using GC-MS and IAA was found in the range of $11.50 \pm 0.77 \mu \mathrm{g} \mathrm{m}^{-1}$ to $38.80 \pm 1.35$ $\mu \mathrm{g} \mathrm{m}{ }^{-1}$. We also assessed the strains for plant growth promoting potential because these isolates were able to produce IAA in pure culture. Most of the growth attributes of rice plants (shoot and root length, fresh and dry biomass, and chlorophyll content) were significantly increased by bacterial endophytes compared to the controls. These results show that IAA producing bacterial endophytes can improve hostplant growth traits and can be used as bio-fertilizers.
\end{abstract}

Keywords: Seed-born bacterial endophytes - IAA production - growth promotion - rice - bio-fertilizers

\section{INTRODUCTION}

The term endophyte refers to microorganisms that live inside plant tissues without causing any disease, and they can be isolated from inside plant tissues by using strict outer surface disinfection methods [30, 35]. Endophytes live in a completely safe and protected environment, compared to organisms living in the rhizosphere and phyllosphere, and this means that they are more bioactive [2]. Although, the term endophytes is mostly related to fungi, there have been reports on bacteria growing inside plant tissues that do not cause any disease $[15,23]$.

\footnotetext{
*Corresponding author; e-mail address: ijlee@knu.ac.kr
} 
The isolation of bacterial endophytes has been widely reported from both monocot and dicot plant species, ranging from herbs to trees $[6,13,17,20]$. The evaluation of a bacterial population inside plant tissues is diverse, and depends on the growth media, isolation method, and the plant part used for isolation of the bacterial endophytes [21]. Bacterial endophytes improve plant growth in several ways, by both direct and indirect behaviors, such as phytohormone secretion, phosphate solubilization, facilitate plant nutrient uptake, phytoremediation, and defending plants from pathogen attack $[3,20]$.

Recently, plant growth promoting rhizobacteria have been applied as bio-inoculant or bio-fertilizers [8]. However, few endophytic bacteria have been used in this manner. Numerous scientists have isolated endophytic bacteria from various parts of the rice plant, for example, the leaves, root, and stem and these have been found to possibly control infection and improve the plant growth $[1,14,16]$. However, seed considered bacterial endophytes are not particularly examined. In contrast, fertilizers have a key role in the promotion of plant growth and intensification of agricultural productivity, but the long-term use of synthetic chemical fertilizers on agricultural fields is a major threat to environmental pollution [31]. Therefore, the use of bacterial endophytes can be a good alternative to chemical fertilizers because they are eco-friendly and promote plant growth [22]. Different plant growth promoting bacteria may fix nitrogen and produce important growth promoting and stress resistant phytohormones, such as auxins, gibberellins, cytokinins, and abscisic acid [20, 32].

Rice is the most important staple crop and dietary source in the world. Historically, rice began to be cultivated almost 10,000 years ago in Asia and China, although it was also cultivated in Europe and America [11]. Rice feeds more than $50 \%$ of the world population [14], and supplies $21 \%$ of human energy and $15 \%$ of our protein requirement. It is also a good income source, so it is important to manage quality and quantity so that production is matched to consumption. This should be done in an environmentally friendly way and without the use of chemical fertilizers, which contaminate the environment and affect human health. However, sustainable farming in an ecofriendly way is needed to ensure food security for a rapidly growing population. This study aimed to isolate and identify the phytobeneficial potentials of bacterial endophytes from the seeds of rice plants and assess their potential for phytohormone production and improving rice plant growth.

\section{MATERIALS AND METHODS}

\section{Isolation of bacterial endophytes}

The bacterial endophytes were isolated according to Taghavi et al. [32] from healthy Japonica rice seeds (Oryza sativa L. var. Jin so mi), which were collected from the genetic seed bank at Kyungpook National University (Korea).

Salkowski's method [11] was used for the initial screening and selection of indoleacetic acid (IAA)-producing bacterial endophytes. All isolated bacterial endo- 
phytes were initially inoculated in LB media and incubated for $48 \mathrm{~h}$ at $28^{\circ} \mathrm{C}$. The broths were centrifuged at $10,000 \times \mathrm{g}$. the supernatants were collected and $1 \mathrm{ml}$ of supernatant from each bacterial isolate was mixed with $1 \mathrm{ml}$ Salkowski reagent. Six (RWL-2, RWL-3, RWL-4, RWL-5, RWL-6, and RWL-7) out of ten endophytes changed the color from yellow to pink, which meant they were producing IAA. These IAA producing bacterial endophytes were selected for further analysis.

\section{PCR amplification and $16 \mathrm{~S}$ rDNA sequencing of selected bacterial isolates}

The selected bacterial isolates were identified by PCR amplification and by sequencing their $16 \mathrm{~S}$ rDNA. A specific $27 \mathrm{~F}$ primer (5'-AGAGTTTGATC (AC) TGGCTCAG-3') and a 1492R primer (5'-CGG (CT) TACCTTGTTACGACTT-3') were used for the PCR as described by Khan et al. [20]. To identify the closest neighbor to each bacterial isolate, their nucleotide sequences underwent a Blast search in the NCBI GenBank database. A phylogenetic analysis was carried out by obtaining related sequences from the NCBI and an evolutionary tree was created using the neighbor-joining analysis method and MEGA software, version 6.0, with 1000 bootstrap values.

\section{GC/MS analysis of bacterial cultures for IAA production}

IAA was quantified in isolated endophytic bacterial culture, positive (Enterobacter sp. SE992) and negative (Escherichia coli KCCM 12119) controls, respectively, three time using GC/MS $[19,33]$. For IAA quantification, the bacterial culture was centrifuged at $10,000 \times g$ at $4{ }^{\circ} \mathrm{C}$ and the supernatant was filtered through a $0.45 \mu \mathrm{m}$ cellulose acetate filter, acidified to $\mathrm{pH} \mathrm{2.8,} \mathrm{and} 40 \mu \mathrm{g} \mathrm{ml}^{-1}$ [D5]-IAA was added. The culture filtrates were then extracted three times with equal amounts of ethyl acetate and completely evaporated through a rotary evaporator. The dried extracts were redissolved in $5 \mathrm{ml} 0.1 \mathrm{M}$ acetic acid and then passed through a reverse-phase C18 column. The methanol fractions were prepared by dissolving the residue in $1 \mathrm{ml}$ of methanol and adding $1.5 \mathrm{ml}$ diazomethane. Finally, the methylated samples were redissolved in ethyl acetate before being analyzed by GC/MS with selected ion monitoring (SIM; 6890N network GC system, and 5973 network mass selective detector; Agilent Technologies, Santa Clara, CA, USA).

\section{Screening for plant growth promoting potential}

To confirm the possible growth promoting potential, the bacterial isolates were bioassayed on their host rice plant. Each strain was cultured in $500 \mathrm{ml} \mathrm{LB}$ broth media for 1 day and shaken in an incubator at $150 \mathrm{rpm}$ and $27^{\circ} \mathrm{C}$. The culture broth was then 
centrifuged at $10,000 \times g$. The cells were suspended in autoclaved double-distilled water and adjusted to 0.5 optical density at $600 \mathrm{~nm}$. The rice seeds were surface sterilized with $2.5 \%$ sodium hypochlorite and carefully washed three times in autoclaved double-distilled water. The seeds were first germinated on sterilized filter paper and equal numbers of seedlings were transferred to a sterilized pot filled with a sand medium [moisture content $18-23 \%, \mathrm{pH} 4.5-5.5$, electrical conductivity (EC) 2.0 $\mathrm{dS} \mathrm{m}{ }^{-1}$, bulk density $0.7-1.0 \mathrm{mg} \mathrm{m}^{-3}$, grain size $125-250 \mu \mathrm{m}$, nitrogen $800-2500$ $\mathrm{mg} \mathrm{kg}$, and phosphorus $150-850 \mathrm{mg} \mathrm{kg}^{-1}$. Other components included zeolite, diatomite, and vermiculite. Root zone applications of $2 \mathrm{ml}$ suspended cells with a 0.5 OD for each isolate were carried out at the two leaf stage. IAA $(10 \mu \mathrm{M}$; SigmaAldrich, USA) and SE992 - Enterobacter sp. were used as positive controls. Along with this, autoclaved double distilled water and E. coli - Escherichia coli KCCM 12119 were used as negative controls.

The plants were grown in a growth chamber (day/night cycle: $14 \mathrm{~h} ; 28^{\circ} \mathrm{C} / 10 \mathrm{~h}$; $24{ }^{\circ} \mathrm{C}$; relative humidity $60-70 \%$; light intensity $1000 \mathrm{~mm}^{-2} \mathrm{~s}$ natrium lamps) for two weeks. The growth parameters, such as shoot and root length, and shoot and root fresh weights, were recorded after harvesting while plant dry weight was observed after drying at $80^{\circ} \mathrm{C}$ in an oven for $48 \mathrm{~h}$. Total chlorophyll contents were measured from fully expanded leaves using a chlorophyll meter (SPAD-502 Minolta, Japan).

\section{Statistical analysis}

The data were statistically analyzed using analysis of variance (ANOVA), and the data was completely randomized. Mean values were compared using LSD and considered significant at the 0.05 probability level.

\section{RESULTS}

\section{Isolation and identification of endophytic bacteria from seeds}

A total of 10 bacterial endophytes were isolated from the seeds of Japonica rice (Oryza sativa L. var. Jin so mi) which were initially screened for IAA production using colorimetric Salkowski assay. Among the 10 strains, six produced IAA in their pure growth culture (Fig. 1). The six selected strains were RWL-2, RWL-3, RWL-4, RWL-5, RWL-6, and RWL-7. These strains were further subjected to molecular identification and IAA quantification using GC/MS SIM.

The bacterial strains were identified by $16 \mathrm{~S}$ rRNA sequencing and their sequences were submitted for comparison with the sequences in the NCBI database (http://www. ncbi.nlm.nih.gov/) by BLASTn search in order to find out the homologous sequences of related strains. The phylogenetic analysis, based on $16 \mathrm{~S}$ rRNA, showed that the six isolates were related to Micrococcus, Enterobacter, Leclercia, Pantoea, and Staphylococcus (Fig. 1), and the neighbor-joining tree, using CLUSTAL-X 1.8 soft- 


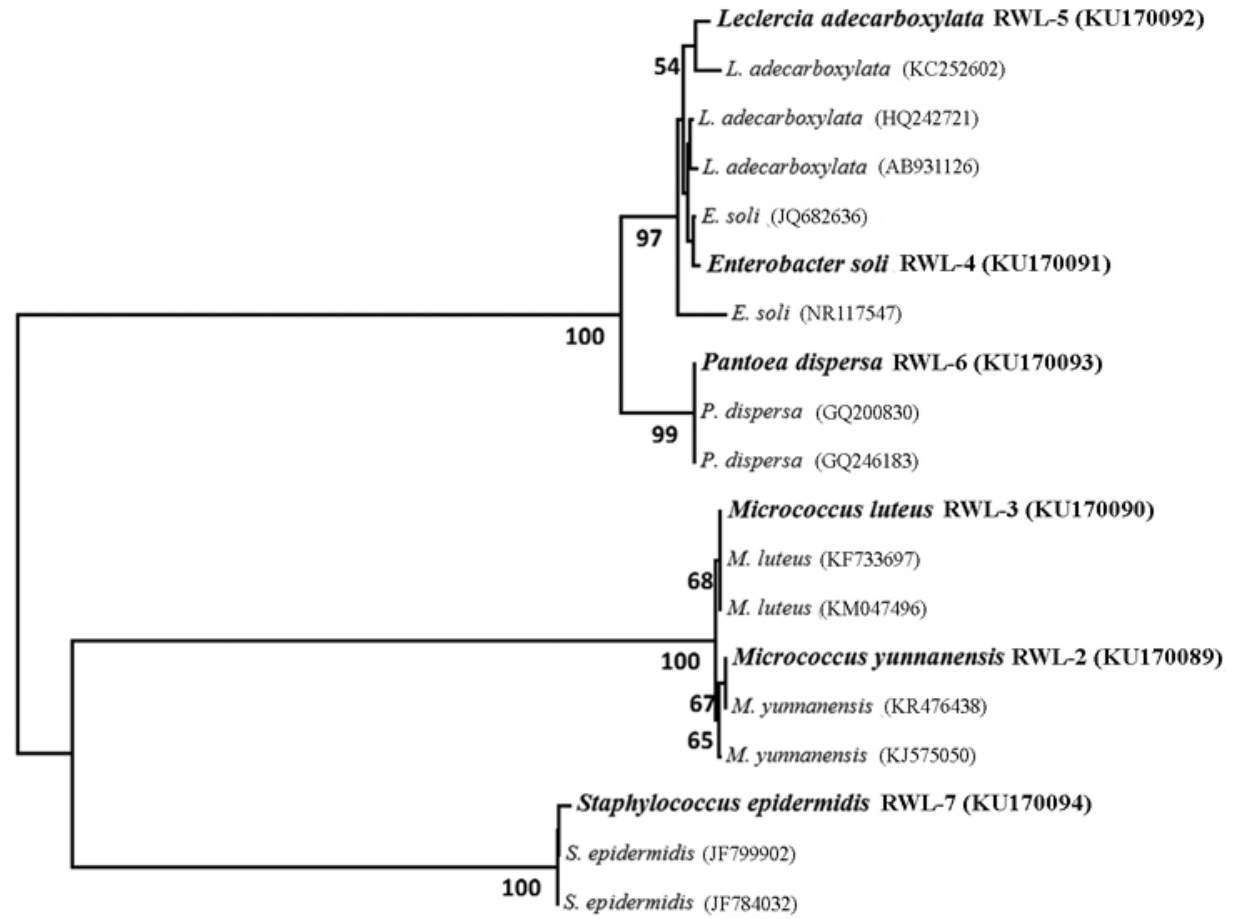

0.02

Fig. 1. Phylogenetic analysis of endophytic bacteria isolated from Japonica rice seed. The neighbor joining tree was created from the $16 \mathrm{~S}$ rRNA genes sequences of the isolated endophytic bacteria and closely associated species retrieved from NCBI database. The percentages shown at each branch points represent the bootstrap values $(1 \mathrm{~K})$

ware, further indicated their phylogenetic position and close relationship with their associated species. The bacterial endophytes strains, along with their NCBI accession numbers, are as follows: Micrococcus yunnanensis RWL-2 (KU170089), Micrococcus luteus RWL-3 (KU170090), Enterobacter soli RWL-4 (KU170091), Leclercia adecarboxylata RWL-5 (KU170092), Pantoea dispersa RWL-6 (KU170093), and Staphylococcus epidermidis RWL-7 (KU170094).

\section{IAA detection and quantification in cultural broth}

The presence and production capacity of IAA in the culture broths of the selected isolates were further confirmed and examined by GC/MS SIM (Fig. 2). The quantification of IAA production in the cultural broths of the selected isolates was obtained by comparing their peak area ratios. The results revealed that the selected six isolates 


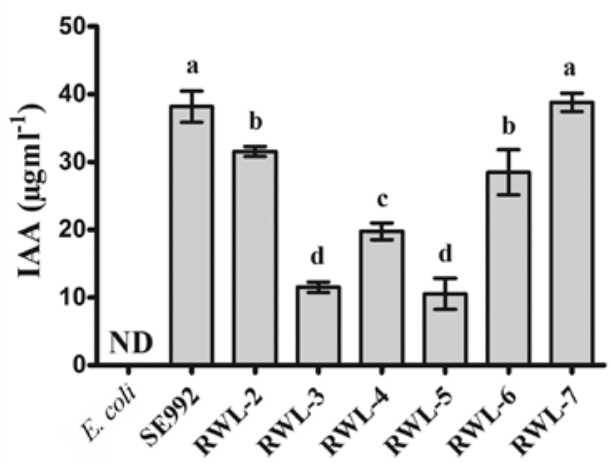

Fig. 2. The indoleacetic acid (IAA) production abilities of endophytic bacterial strains isolated from Japonica rice seed. The IAA produced in the culture broth was purified and then quantified against labeled IAA standard isotopes using GC/MS-SIM. RWL-2 - Micrococcus yunnanensis, RWL-3 - Micrococcus luteus, RWL-4 - Enterobacter soli, RWL-5 - Leclercia adecarboxylata, RWL-6 - Pantoea dispersa, RWL-7- Staphylococcus epidermidis. SE992 - Enterobacter $\mathrm{sp}$. - a bacterial strain known to produce significant amount of auxin and non-IAA producing E. coli - Escherichia coli KCCM 12119 were used as a positive and negative controls, respectively. Columns with error bars represent mean \pm SD from the pooled data of three repeated experiments. Columns with different letters are significantly different at the 0.05 level of probability as identified by the LSD test

produced significant amounts of IAA (Fig. 2). The maximum amount of IAA was detected in the culture broth of $S$. epidermidis RWL-7 $\left(38.80 \mu \mathrm{g} \mathrm{ml}^{-1}\right)$ followed by M. yunnanensis RWL-2 (31.55 $\left.\mu \mathrm{g} \mathrm{ml}^{-1}\right)$, P. dispersa RWL-6 $\left(28.47 \mu \mathrm{g} \mathrm{ml}^{-1}\right)$, E. soli RWL-4 (19.77 $\left.\mu \mathrm{g} \mathrm{ml}^{-1}\right)$, and $M$. luteus RWL-3 $\left(11.50 \mu \mathrm{g} \mathrm{ml}^{-1}\right)$, while the lowest IAA production was observed in L. adecarboxylata RWL-5 (10.53 $\left.\mu \mathrm{g} \mathrm{ml}^{-1}\right)$ (Fig. 2).

No IAA was detected in the culture broth of negative control E. coli. However, Enterobacter sp. SE992 produced (38.16 $\left.\mu \mathrm{g} \mathrm{ml}^{-1}\right)$ of IAA (Fig. 2).

\section{Growth promoting potential of bacterial endophytes}

The growth promoting nature of selected isolates was shown by the introduction of their cells into host plants and then examining their effect on shoot and root length, seedlings fresh and dry weight, and chlorophyll contents. The results showed that inoculation with selected bacterial endophytes significantly increased the host-plant growth attributes compared to the positive and negative controls (Table 1 and Fig. 3). The shoot lengths were significantly increased in RWL-7 followed by RWL-6, while the minimum shoot length was observed in the negative control-distilled water. The maximum root length was observed in plants inoculated with RWL-2 followed by RWL-4 while the minimum root length was recorded in negative control-distilled water. Seedling fresh weight and dry weights significantly increased in RWL-7, followed by RWL-6, while the seedlings fresh and dry weights were lowest for the negative control. Chlorophyll contents significantly increased in all treated plants compared to the positive and negative controls. The maximum chlorophyll contents 


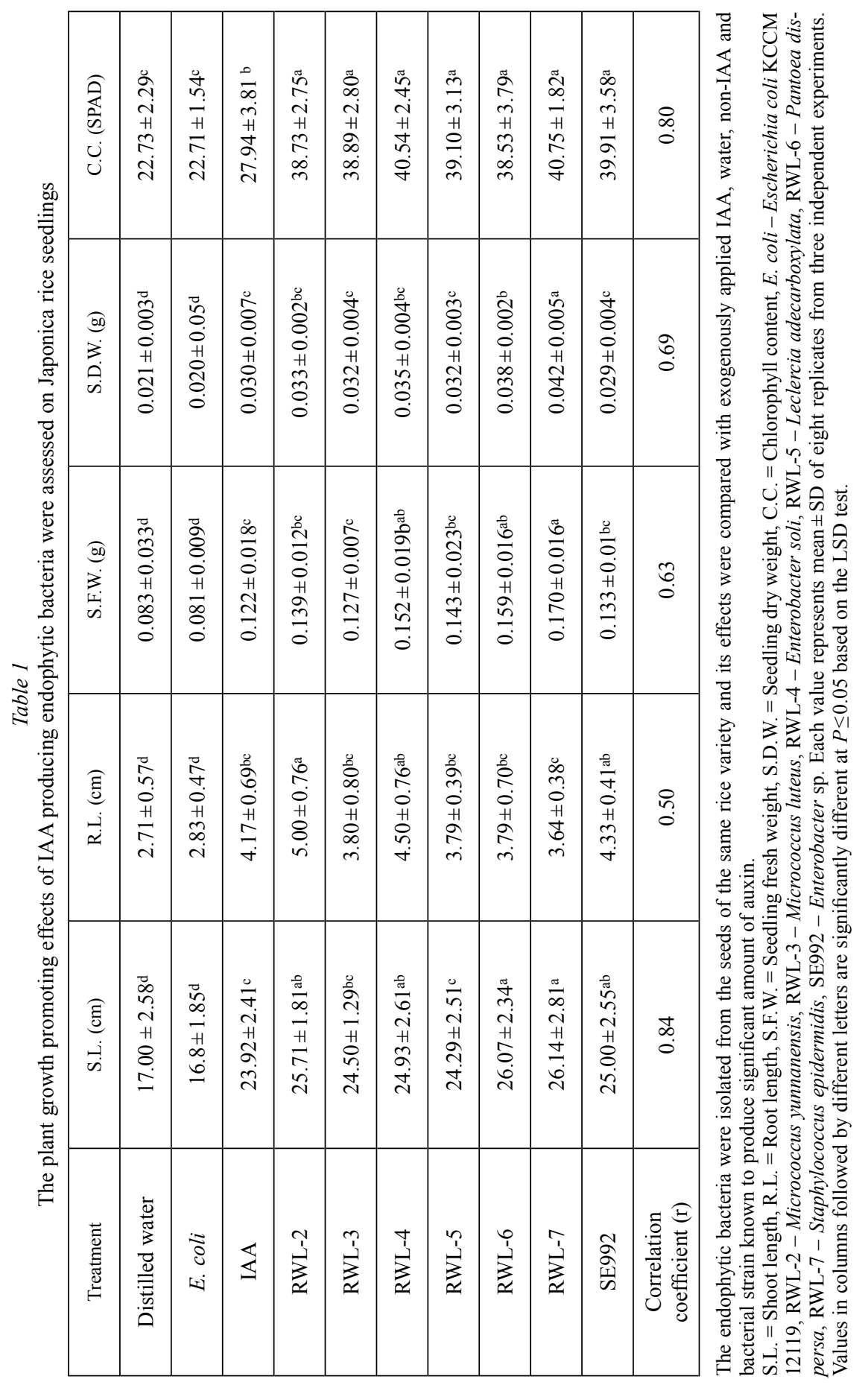

Acta Biologica Hungarica 68, 2017 


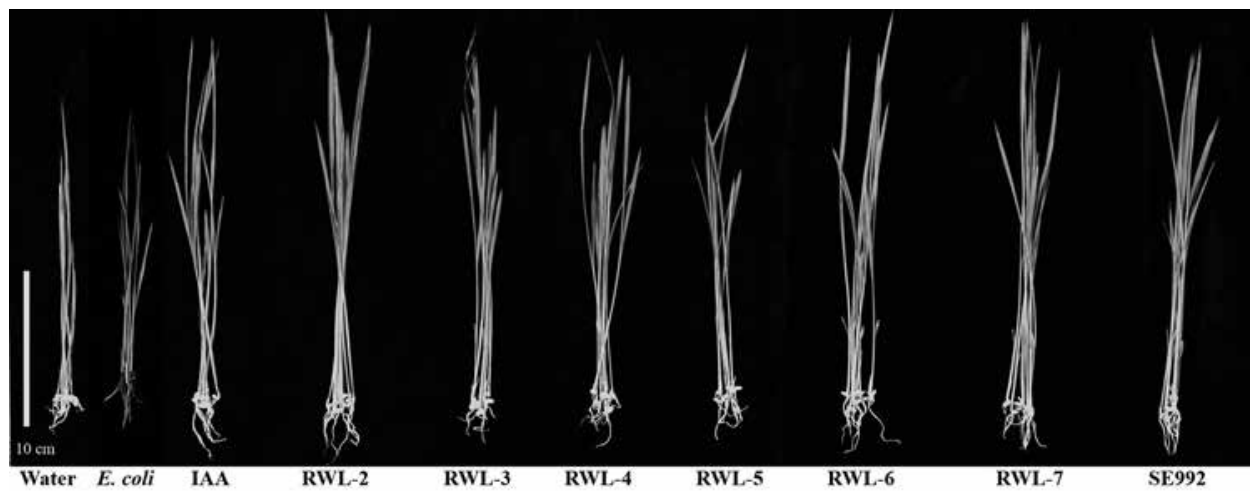

Fig. 3. Growth promoting effect of selected IAA producing endophytic bacteria isolated from Japonica rice seed. The bacterial cells were applied to the rice root zone and growth promoting effects were compared with both positive (exogenous IAA, SE992 - Enterobacter sp., known to produce auxin) and negative (water, E. coli - Escherichia coli KCCM 12119, does not produce IAA) controls. The picture is the representative of plant samples from three experiments. The abbreviations stand for RWL-2 - Micrococcus yunnanensis, RWL-3 - Micrococcus luteus, RWL-4 - Enterobacter soli, RWL-5 - Leclercia adecarboxylata, RWL-6 - Pantoea dispersa, RWL-7 - Staphylococcus epidermidis. Scale bar given on the left of figure is equal to $10 \mathrm{~cm}$

were observed in RWL-7 and were not significantly different from other bacterial and exogenous IAA-treated plants while the chlorophyll contents were significantly reduced in the negative control (Table 1).

Negative control (E. coli) did not evoke any growth promoting effects on physiological characteristics and the results resembled those of distilled water (Table 1 and Fig. 3). Moreover, the positive control (SE992) significantly promoted rice growth and the results were at par with those of growth enhancing IAA producing bacterial endophytes.

\section{DISCUSSION}

Excessive use of chemical fertilizer is adversely affecting agricultural productivity and the sustainability of plant associated ecosystems. To date, numerous studies have investigated using plant growth promoting rhizobacteria (PGPRs) to mitigate the adverse effects of stresses on crops [9, 10, 18, 19, 25, 28]. Such endophytic bacteria colonize healthy plant tissues without causing any disease symptoms to the host plants. Endophytes have been regarded as the most prolific class of microorganisms that can help host plants to counteract the negative impacts of biotic and abiotic stress conditions $[5,24]$. Endophytic bacteria can be an alternative to chemical fertilizers as the use of bacterial endophytes has been practiced throughout the world to replace the use of chemical fertilizer [26]. Among other ways of promoting growth, bacterial endophytes encourage plant growth by producing phytohormones [20]. In this study, we isolated six bioactive IAA producing endophytic bacteria. 
Many researchers have isolated endophytic bacteria from different parts of the rice plant, such as the leaves, root, and stem and these have been found to potentially control disease and enhance growth $[1,14,16]$. However, seed conceived bacterial endophytes are not particularly investigated. Hardoim et al. [16] reported that rice seeds were an important source of bacterial endophytes and their results revealed that the endophytes isolated from rice seeds usually rapidly adopt and colonize rice shoot tissues because there is less competition than in the roots. This means they can comparatively rapidly enhance plant growth.

IAA production by different bacterial strains isolated from different parts of the plant (endosphere, rhizosphere) has been widely reported. The IAA producing bacterial endophytes isolated in this study belong to different bacterial genera or species. Our results are in line with other reports, for example Arthrobacter was isolated from walnut trees and found to promote host plant growth [36]. IAA is one of the important phytohormones which plays an important role in plant growth promotion and alleviates different biotic and abiotic stresses. IAA production varies among bacterial species and strains [27]. Therefore the selected bacterial isolates were subjected to $\mathrm{GC} /$ MS to accurately detect the amount of IAA produced (Fig. 2). Ullah et al. [33] and Kang et al. [19] also utilized this method to detect the IAA in the culture filtrate of entomopathogenic bacteria and PGPR, respectively. The differences in the IAA production ability of our selected isolates were in line with the findings of Cohen et al. [7], Mutluru and Konada [27], and Boiero et al. [4]. Similarly, Khan et al. [20] isolated an endophytic bacterium Bacillus subtilis LK14 from an arid land tree Moringa peregrina, which produced large amounts of IAA in pure culture. The endophytic strain, when applied to tomato plants, significantly increased the plant growth and development and confirmed our findings. The plant growth enhancing potential, in terms of shoot and root length, fresh and dry biomass, and chlorophyll contents, were in line with Khan et al. [20], Ullah et al. [33], Kang et al. [19], Wahyudi et al. [34], and Spaepen et al. [29].

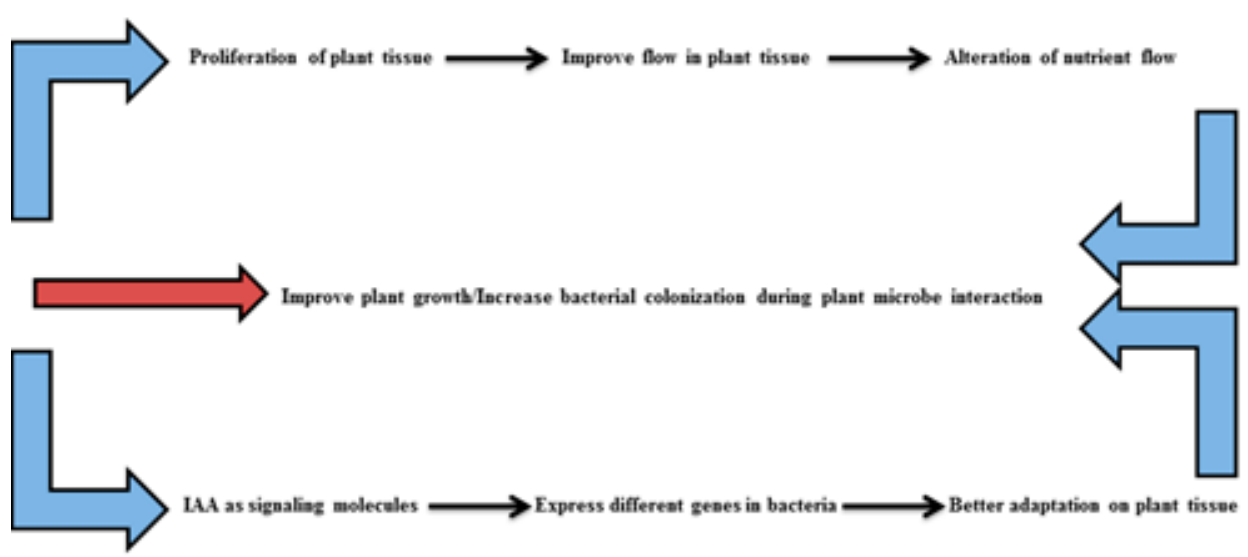

Fig. 4. Plant growth promoting mechanism of IAA producing bacteria. The figure illustrates the most important known process of symbiotic association that may enable IAA producing endophytic bacteria to promote plant growth and alleviate stress effects 
It is now known that IAA can be produced by variety of endophytes [20]. IAA plays a vital role in plant development as indole-3-acidic acid (IAA) being an auxin that can empower both fast response like cell elongation and long term response like cell division and differentiation in plants and at the same time (Fig. 4), its additional supply can support host growth during stress conditions [32]. There are various types of rhizospheric bacteria that have been shown to produce IAA and exploit different IAA biosynthesis pathways. A single bacterial strain can sometimes encompass more than one pathway [37]. IAA production by bacteria can vary among different species and strains, and it is also influenced by culture conditions, growth stage, and substrate availability $[7,21,27]$.

\section{CONCLUSION}

In conclusion, bacterial endophytes produce important growth regulating secondary metabolites that can help improving the growth of host and other related plants. Such bacterial endophytes can be trialed at the field level to assess their potential as a biofertilizer, in synergism with plant growth promoting rhizobacteria.

\section{ACKNOWLEDGEMENT}

This research was supported by the Basic Science Research Program through the National Research Foundation of Korea (NRF) funded by the Ministry of Education (2016R1A6A1A05011910).

\section{REFERENCES}

1. Adhikari, T. B., Joseph, C. M., Yang, G., Phillips, D. A., Nelson, L. M. (2001) Evaluation of bacteria isolated from rice for plant growth promotion and biological control of seedling disease of rice. Can. J. Microbiol. 47, 916-924.

2. Andrews, J. H. (1992) Biological control in the phyllosphere. Ann. Rev. Phytopathol. 30, 603-635.

3. Aylward, F. O., McDonald, B. R., Adams, S. M., Valenzuela, A., Schmidt, R. A., Goodwin, L. A., Woyke, T., Currie, C. R., Suen, G., Poulsen, M. (2013) Comparison of 26 Sphingomonad genomes reveals diverse environmental adaptations and biodegradative capabilities. App. Environ. Microbiol. 79, 3724-3733

4. Boiero, L., Perrig, D., Masciarelli, O., Penna, C., Cassan, F., Luna, V. (2007) Phytohormone production by three strains of Bradyrhizobium japonicum and possible physiological and technological implications. Appl. Microbiol. Biotechnol. 74, 874-880.

5. Boshra, A. H., Khan, A. L., Waqas, M., Al-Harrasi, A., Hussain, J., Ali, L., Adnan, M., Lee, I. J. (2015) Endophytic bacteria (Sphingomonas sp. LK11) and gibberellin can improve Solanum lycopersicum growth and oxidative stress under salinity. J. Plant Intera 10, 117-125.

6. Brooks, D. S., Gonzalez, C. F., Appel, D. N., Filer, T. H. (1994) Evaluation of endophytic bacteria as potential biological control agents for oak wilt. Biol. Control 4, 373-381.

7. Cohen, A. C., Bottini, R., Piccoli, P. N. (2008) Azospirillum brasilense Sp. 245 produces ABA in chemically-defined culture medium and increases ABA content in Arabidopsis plants. Plant Growth Regul. 54, 97-103. 
8. Croes, S., Weyens, N., Colpaert, J., Vangronsveld, J. (2015) Characterization of the cultivable bacterial populations associated with field grown Brassica napus L.: an evaluation of sampling and isolation protocols. Envi. Microbiol. 17, 2379-2392.

9. de-Bashan, L. E., Hernandez, J. P., Morey, T., Bashan, Y. (2004) Microalgae growth-promoting bacteria as "helpers" for microalgae: a novel approach for removing ammonium and phosphorus for municipal wastewater. Water Res. 38, 466-474.

10. Egamberdieva, D., Lugtenberg, B. (2014) Use of plant growth-promoting rhizobacteria to alleviate salinity stress in plants. In: Miransari, M. (ed.) Use of microbes for the alleviation of soil stresses, Vol. 1. Spinger, New York.

11. Ehmann, A. (1977) The Van Urk-Salkowski reagent-a sensitive and specific chromogenic reagent for silica gel thin-layer chromatographic detection and identification of indole derivatives. Journal of Chromatography A 11, 132, 267-276.

12. Gnanamanickam, S. S. (2009) Rice and its importance to human life. Prog. Biol. Con. 8, 1-11.

13. Gutiérrez-Zamora, M. L., Martinez-Romero, E. (2001) Natural endophytic association between Rhizobium etli and maize (Zea mays L.). J. Biotechnol. 91, 117-126.

14. Gyaneshwar, P., Mathan, E. K. J. N., Reddy, P. M., Hurek, B. R., Ladha, J. (2001) Endophytic colonization of rice by a diazotrophic strain of Serratia marcescens. J. Bacteriol. 183, 2634-2645.

15. Hironobu, M., Hisao, M. (2008) Endophytic bacteria in the rice plant. Microbes Environ. 23, 109117.

16. Hardoim, P. R., Hardoim, C. C. P., Van-Overbeek, L. S., Van-Elsas, J. D. (2012) Dynamics of seedborne rice endophytes on early plant growth stages. PLoS ONE 7(2): e30438

17. Janso, J. E., Carter, G. T. (2010) Biosynthetic potential of phylogenetically unique endophytic actinomycetes from tropical plants. Appl. Environ. Microbiol. 76, 4377-4386.

18. Kang, S. M., Ramalingam, R., Khan, A. L., Kim, M. J., Park, J. M., Kim, B. R. et al. (2014) Gibberellin secreting rhizobacterium, Pseudomonas putida $\mathrm{H}-2-3$ modulates the hormonal and stress physiology of soybean to improve the plant growth under saline and drought conditions. Plant Physiol. Biochem. 84, 115-124.

19. Kang, S. M., Radhakrishnan, R., Lee, S. M., Park, Y. G., Kim, A. Y., Seo, C. W., Lee, I. J. (2015) Enterobacter sp. SE992-induced regulation of amino acids, sugars, and hormones in cucumber plants improves salt tolerance. Acta Physiol. Plant 37, 149.

20. Khan, A. L., Waqas, M., Kang, S. M., Al-Harrasi, A., Hussain, J., Al-Rawahi, A., Al-Khiziri, S., Ullah I., Ali, L., Jung, H. Y., Lee, I. J. (2014) Bacterial endophyte Sphingomonas sp. LK11 produces gibberellins and IAA and promotes tomato plant growth. J. Microbiol. 52, 689-695.

21. Kloepper, J. W., Beauchamp, C. J. (1992) A review of issues related to measuring colonization of plant roots by bacteria. Can. J. Microbiol. 38, 1219-1232.

22. Kong, Q. K., Ding, A. Y. (2001) Advances of study on endophytic bacteria as biological contro agents. J. Shandong Agric. Univers Nat. Sci. 32, 256-260.

23. Lodewyckx, C., Vangronsveld, J., Porteous, F., Moore, E. R. B., Taghavi, S., Mezgeay, M., Van-der, L. D. (2002) Endophytic bacteria and their potential applications. Cri. Rev. Plant Sci. 21, 583-606.

24. Mandyam, K., Jumpponen, A. (2014) Unraveling the dark septate endophyte functions: insights from the Arabidopsis model. In: Verma, V. C., Gange, A. C. (eds) Advances in endophytic research. Springer, India.

25. Mayak, S., Tirosh, T. R., Glick, B. (2004) Plant growth-promoting bacteria that confer resistance to water stress in tomatoes and peppers. Plant Sci. 166, 525-530.

26. Montañez, A., Rodríguez, B. A., Barlocco, C., Beracochea, M., Sicardi, M. (2012) Characterization of cultivable putative endophytic plant growth promoting bacteria associated with maize cultivars (Zea mays L.) and their inoculation effects in vitro. App. Soil Ecol. 58, 21-28.

27. Mutluru, S., Konada, V. M. (2007) Bioproduction of indole acetic acid by Rhizobium strains isolated from root nodules of green manure crop, Sesbania sesban (L.) Merr. Iran J. Biotechnol. 5, 178-182.

28. Shimaila, A., Trevor, C. C., Glick, R. B. (2014) Amelioration of high salinity stress damage by plant growth-promoting bacterial endophytes that contain ACC deaminase. Plant Physiol. Biochem. 80, $160-167$. 
29. Spaepen, S., Vanderleyden, J., Okon, Y. (2009) Plant growth-promoting actions of rhizobacteria. $A d v$ Botan. Res. 51, 283-320.

30. Sturz, A. V., Christie, B. R., Nowak, J. (2000) Bacterial endophytes: potential role in developing sustainable systems of crop production. Crit. Rev. Plant Sci. 19, 1-30.

31. Sun, R., Guo, X., Wang, D., Chu, H. (2015) Effects of long-term application of chemical and organic fertilizers on the abundance of microbial communities involved in the nitrogen cycle. App. Soil Ecol. 95, 171-178.

32. Taghavi, S., Garafola, C., Monchy, S., Newman, L., Hoffman, A., Weyens, N., Barac, T. Vangronsveld, J., Van-der, L. D. (2009) Genome survey and characterization of endophytic bacteria exhibiting a beneficial effect on growth and development of poplar trees. App. Environ. Microbiol. 75, $748-757$.

33. Ullah, I., Khan, A., Park, G.-S., Lim, J.-H., Waqas, M., Lee, I.-J., Shin, J.-H. (2013) Analysis of phytohormones and phosphate solubilization in Photorhabdus spp. Food Sci. Biotechnol. 22, 25-31.

34. Wahyudi, A. T., Astuti, R. P., Widyawati, A., Meryandini, A., Nawangsih, A. A. (2011) Characterization of Bacillus sp. strains isolated from rhizosphere of soybean plants for their use as potential plant growth for promoting Rhizobacteria. J. Microbiol. Antimicrobial. 3, 34-40.

35. Waqas, M., Khan, A. L., Kamran, M., Hamayun, M., Kang, S.-M., Kim, Y.-H., Lee, I.-J. (2012) Endophytic fungi produce gibberellins and indoleacetic acid and promotes host-plant growth during stress. Molecules 17, 10754-10773.

36. Xuan, L., Zhu, T.-H., Liu, G.-H., Mao, C. (2012) Co-inoculation with phosphate-solubilizing and nitrogen-fixing bacteria on solubilization of rock phosphate and their effect on growth promotion and nutrient uptake by walnut. Eur. J. Soil Biol. 50, 112-117.

37. Zhao, Y. (2010) Auxin biosynthesis and its role in plant development. Annu. Rev. Plant Biol. 61, 49-64. 